\title{
MOVEMENT COORDINATION: IDENTIFICATION OF AGE-RELATED DYNAMICS OF ITS DEVELOPMENT IN GIRLS AGED 11-13
}

\author{
Ivashchenko O.V. ${ }^{1}$, Khudolii O.M. ${ }^{1}$, Iermakov S.S. ${ }^{2}$, Prykhodko V.V. ${ }^{3}$, Cieslicka M. ${ }^{4}$ \\ ${ }^{1}$ Faculty of Physical Education and Sports, H. S. Skovoroda Kharkiv National Pedagogical \\ University, Ukraine \\ ${ }^{2}$ Department of Tourism and Recreation, Gdansk University of Physical Education and \\ Sport, Poland \\ ${ }^{3}$ StartSchool, Kharkiv, Ukraine \\ ${ }^{4}$ Kazimierz Wielki University, Bydgoszcz, Poland
}

Corresponding Author: Ivashchenko Olha, e-mail: olga@tmfv.com.ua

Accepted for Publication: June 21, 2018

Published: June 30, 2018

DOI:10.17309/tmfv.2018.2.06

\begin{abstract}
The study objective is to determine the possibility of identifying the state of coordination abilities development in girls aged 11-13 using the methodology of multidimensional statistics.

Materials and methods. The study involved girls aged $11(n=20), 12(n=23), 13(n=19)$. To evaluate motor preparedness, the study recorded the results of motor tests, body height and weight. The IBM SPSS 20 statistical analysis software was used to process the study materials. A discriminant analysis was performed.

Results. To identify the level of coordination abilities development in girls aged 11, 12 and 13, the following tests can be used: test 4 "Pull-ups (number of times)", test 2 "Standing long jump (cm)", test 6 "Evaluation of the sense of movement speed in sprinting", and test 9 "Static equilibrium evaluation by E. Ya. Bondarevsky's method", which characterize relative and speed strength, the sense of running speed and vestibular stability.

To identify the state of coordination abilities development in girls aged 12-13, the following tests can be used: test 12 "Rhythmic hand tapping", test 13 "Rhythmic movements of upper and lower limbs", test 5 "Sit-ups in 30 seconds", test 7 "Evaluation of the ability to differentiate movement speed (reproduction accuracy of running speed at $80 \%$ intensity of maximum)", which characterize the movement coordination of different parts of the body, strength endurance of abdominal muscles, and the evaluation of the ability to differentiate movement speed. Conclusions. A discriminant analysis made it possible to determine informative indicators for a comprehensive control of coordination abilities development in girls aged 11-13; to answer the questions as to how the states of coordination abilities development in girls aged 11, 12 and 13 significantly differ; what motor tests most substantially influence the differentiation of classes; what class the object belongs to based on the values of discriminant variables.
\end{abstract}

Keywords: coordination abilities, discriminant analysis, pedagogical control.

\section{Introduction}

Physical activity and its impact on population health is one of the research problems in physical education (Bădicu, \& Balint, 2016; Bădicu, 2018). Physical education of schoolchildren aims at optimizing children's physical development (Balsevich, 2000; Ilyin, 2003), improving their motor abilities, promoting and protecting their health (Ivashchenko, 2016; Emeljanovas, Mieziene, \& Putriute, 2015). Coordination abilities are part of the basic ones and can be developed in school age (Balsevich, 2000; Liakh, 2000).

(C) Ivashchenko O.V., Khudolii O.M., Iermakov S.S., Prykhodko V.V., Cieslicka M., 2018.
Numerous studies have reached conclusions on the following points:

- the effectiveness of comprehensive development of strength, dexterity, coordination, endurance, and flexibility in children (Liakh, 2000; Krutsevych, \& Bezverkhnia, 2010);

- the influence of the level of movement coordination development on the process of teaching physical exercises to schoolchildren (Khudolii, Ivashchenko, \& Chernenko, 2015; Ivashchenko, 2016; Ivashchenko, \& Kapkan, 2016);

- the interrelation of anthropometric, motor and cognitive abilities of children (Iadreev, 
Cherkashin, Vujkov, \& Drid, 2015; Novak, Podnar, Emeljanovas, \& Marttinen, 2015);

- the relationship between the body mass index, subcutaneous fat and the manifestation of movement coordination in children aged 11-14 (Drid, Vujkov, Jaksic, Trivic, Marinkovic, \& Bala, 2013);

- the influence of visual perception on children's movement coordination of different parts of the body (Agricola, Psotta, Abdollahipour, \& Nieto, 2015; Palomo-Nieto, Psotta, Agricola, Abdollahipour, \& Valtr, 2015);

- the effect of loads on the plasticity of motor skills in schoolchildren (Hadžić, Bjelica, Vujović, \& Popović, 2015; Khudolii, \& Ivashchenko, 2014).

Previously published works focused on clarifying the concept of coordination abilities (Liakh, 2000; Ilyin, 2003), as well as on determining their structure (Ivashchenko, Khudolii, Iermakov, Lochbaum, Cieslicka, Zukow, Nosko, \& Yermakova, 2016; Khudolii, Iermakov, \& Prusik, 2015).

Research has found that coordination abilities are of key importance in children's and adolescents' motor preparedness (Serhiienko, Chekmarova, \& Khadzhynov, 2012; Khudolii, 2008). When studying the structure of schoolchildren's motor preparedness, it is effective to use multidimensional methods of mathematical statistics, such as factor and discriminant analyses (Ivashchenko, 2016; Lopatiev, Ivashchenko, Khudolii, Pjanylo, Chernenko, \& Yermakova, 2017). A factor analysis allowed to determine the structure of coordination abilities development in 5th-7th grade boys and girls. (Prykhodko, 2017; Ivashchenko, Prykhodko, \& Cieslicka, 2018). In available literature, however, there are not enough data on the peculiarities of coordination abilities development in middle school students.

Therefore, it is relevant to study the dynamics peculiarities of coordination abilities development by identifying their state of development in middle school girls.

The study objective is to determine the possibility of identifying the state of coordination abilities development in girls aged 11-13 using the methodology of multidimensional statistics.

\section{Materials and methods}

Study participants. The study involved girls: aged 11 $(\mathrm{n}=20), 12(\mathrm{n}=23), 13(\mathrm{n}=19)$.

Study organization. The study used analysis and generalization of scientific literature data, testing, methods of mathematical statistics.

Testing procedure. The testing program included well-known tests (Liakh, 2000; Serhiienko, 2001; Ivashchenko, 2016). To evaluate motor preparedness, the study recorded the results of motor tests, body height and weight:

- Test 1 "30 m running (s)";

- Test 2 "Standing long jump $(\mathrm{cm})$ ";
- Test 3 "Six standing accuracy ball handlings to a partner from a $7 \mathrm{~m}$ distance using one of the techniques learned";

- Test 4 "Pull-ups (number of times)";

- Test 5 "Sit-ups in 30 seconds";

- Test 6 "Evaluation of the sense of movement speed in sprinting";

- Test 7 "Evaluation of the ability to differentiate movement speed (reproduction accuracy of running speed at $80 \%$ intensity of maximum)";

- Test 8 "Evaluation of the ability to differentiate movement speed (reproduction accuracy of running speed at $90 \%$ intensity of maximum)";

- Test 9 "Static equilibrium evaluation by E. Ya. Bondarevsky's method";

- Test 10 "Evaluation of dynamic equilibrium by the BESS method";

- Test 11 "Evaluation of the ability for vestibular (statokinetic) stability. Running with turns";

- Test 12 "Rhythmic hand tapping";

- Test 13 "Rhythmic movements of upper and lower limbs";

- Test 14 "Shuttle run $(4 \times 9 \mathrm{~m})$ ";

- Test 15 "Tossing a ring over a peg";

- Test 16 "Height (cm)";

- Test 17 "Body weight (kg)".

Statistical analysis. The IBM SPSS 20 statistical analysis software was used to process the study materials. In the process of discriminant analysis, the study created a prognostic model for group membership. This model develops a discriminant function (or, when there are more than two groups - a set of discriminant functions) in the form of a linear combination of predictor variables, ensuring the best division of groups. These functions are developed according to a set of observations, for which their group membership is known. These functions can continue to be used for new observations with known values of predictor variables and unknown group membership.

For every variable, the study calculated the following: mean values, standard deviations, single-factor dispersion analysis (Box's $\mathrm{M}$ test, in-group correlation matrix, in-group covariance matrix, covariance matrices for separate groups, general covariance matrix). For every canonical discriminant function, the study calculated: eigenvalue, dispersion percentage, canonical correlation, Wilks' Lambda, Chi-square. For every step, it calculated: prior probabilities, Fisher's function coefficients, unstandardized function coefficients, Wilks' Lambda for every canonical function.

The study protocol was approved by the Ethical Committee of H. S. Skovoroda Kharkiv National Pedagogical University. In addition, the children and their parents or legal guardians were fully informed about all the features of the study, and a signed informed-consent document was obtained from all the parents. 


\section{Study results}

The tables show the results of the discriminant analysis, which allow to identify the state of movement coordination development in the girls aged 11-13.

The first canonical function explains $82.3 \%$ of the results variation, the second one $-17.7 \%$, which indicates their informative value (see Table 1). The coefficients of canonical correlation $(\mathrm{r}=0.880 ; \mathrm{r}=0.651)$ indicate the prognostic value of the first and second functions.

Table 2 shows the analysis of the canonical functions. The first line contains the value $\lambda=0.130(\mathrm{p}=0.001)$ for the entire set of canonical functions, the second line contains the data after the exclusion of the first function $(\lambda=0.576 ; \mathrm{p}=0.031)$. The first and second functions have a high discriminative ability and value of interpretation with regard to the general totality.

Table 3 shows the standardized canonical discriminant function coefficients, which allow to determine the contribution ratio of variables to the function result. Variables 16, 4, 9 make the greatest contribution to the first canonical function: the larger the values of these variables, the larger the value of the function. Variables 6, 2, 12 contribute most to the second canonical function: the larger the values of these variables, the larger the value of the function.

In identifying the state of coordination abilities development in the girls aged 11-13, the most important results were obtained in the following tests: test 4 "Pullups (number of times)" (0.468), test 9 "Static equilibrium evaluation by E. Ya. Bondarevsky's method” (0.327). These tests characterize strength abilities and vestibular analyzer stability.

In identifying the state of coordination abilities development in the girls aged 12-13, the most important results were obtained in the following tests: test 6 "Evaluation of the sense of movement speed in sprinting" (0.799), test 2 "Standing long jump (cm)" (0.618), test 12 "Rhythmic hand tapping" (-0.581). These tests characterize the ability to control movements by time in short distance running, speed and strength abilities, and the coordination of arm movements.

Table 1. Summary of Canonical Discriminant Functions. Eigenvalues. Girls aged 11-13

\begin{tabular}{|c|c|c|c|c|}
\hline Function & Eigenvalue & $\%$ of Variance & Cumulative \% & Canonical Correlation \\
\hline 1 & 3.420 & 82.3 & 82.3 & .880 \\
\hline 2 & .736 & 17.7 & 100.0 & .651 \\
\hline
\end{tabular}

Table 2. Canonical discriminant functions. Wilks> Lambda. Girls aged 11-13

\begin{tabular}{lcccc}
\hline Test of Function(s) & Wilks' Lambda & Chi-square & df & Sig. \\
\hline 1 through 2 & .130 & 103.917 & 34 & 0.000 \\
2 & .576 & 28.124 & 16 & 0.031 \\
\hline
\end{tabular}

Table 3. Standardized canonical discriminant function coefficients. Girls aged 11-13

\begin{tabular}{|c|c|c|c|}
\hline \multirow{2}{*}{ No. } & \multirow{2}{*}{ Test } & \multicolumn{2}{|c|}{ Function } \\
\hline & & 1 & 2 \\
\hline 1. & $30 \mathrm{~m}$ running $(\mathrm{s})$ & -.038 & -.104 \\
\hline 2. & Standing long jump $(\mathrm{cm})$ & .186 & .618 \\
\hline 3. & $\begin{array}{l}\text { Six standing accuracy ball handlings to a partner from a } 7 \mathrm{~m} \text { distance using one of the techniques } \\
\text { learned }\end{array}$ & -.144 & .015 \\
\hline 4. & Pull-ups (number of times) & .468 & -.334 \\
\hline 5. & Sit-ups in 30 seconds & .154 & -.414 \\
\hline 6. & Evaluation of the sense of movement speed in sprinting & -.283 & .799 \\
\hline 7. & $\begin{array}{l}\text { Evaluation of the ability to differentiate movement speed (reproduction accuracy of running speed } \\
\text { at } 80 \% \text { intensity of maximum) }\end{array}$ & -.003 & .441 \\
\hline 8. & $\begin{array}{l}\text { Evaluation of the ability to differentiate movement speed (reproduction accuracy of running speed } \\
\text { at } 90 \% \text { intensity of maximum) }\end{array}$ & .247 & -.182 \\
\hline 9. & Static equilibrium evaluation by E. Ya. Bondarevsky’s method & .327 & .450 \\
\hline 10. & Evaluation of dynamic equilibrium by the BESS method & -.138 & .288 \\
\hline 11. & Evaluation of the ability for vestibular (statokinetic) stability. Running with turns & .222 & .200 \\
\hline 12. & Rhythmic hand tapping & -.300 & -.581 \\
\hline 13. & Rhythmic movements of upper and lower limbs & -.227 & -.147 \\
\hline 14. & Shuttle run $(4 \times 9 \mathrm{~m})$ & .232 & -.227 \\
\hline 15. & Tossing a ring over a peg & .293 & -.036 \\
\hline 16. & Height $(\mathrm{cm})$ & .590 & -.181 \\
\hline 17. & Body weight (kg) & -.179 & .136 \\
\hline
\end{tabular}


Table 4. Structure matrix. Girls aged 11-13

\begin{tabular}{|c|c|c|c|}
\hline \multirow{2}{*}{ No. } & \multirow{2}{*}{ Test } & \multicolumn{2}{|c|}{ Function } \\
\hline & & 1 & 2 \\
\hline 4. & Pull-ups (number of times) & $.494^{\star}$ & -.136 \\
\hline 16. & Height $(\mathrm{cm})$ & $.419^{*}$ & .018 \\
\hline 2. & Standing long jump $(\mathrm{cm})$ & $.389^{*}$ & .215 \\
\hline 6. & Evaluation of the sense of movement speed in sprinting & $-.344^{*}$ & .187 \\
\hline 9. & Static equilibrium evaluation by E. Ya. Bondarevsky's method & $.340^{*}$ & .153 \\
\hline 17. & Body weight $(\mathrm{kg})$ & $.251^{\star}$ & .062 \\
\hline 1. & $30 \mathrm{~m}$ running $(\mathrm{s})$ & $-.216^{*}$ & .028 \\
\hline 11. & Evaluation of the ability for vestibular (statokinetic) stability. Running with turns & $.139^{*}$ & .124 \\
\hline 8. & $\begin{array}{l}\text { Evaluation of the ability to differentiate movement speed (reproduction accuracy of running speed } \\
\text { at } 90 \% \text { intensity of maximum) }\end{array}$ & $.128^{\star}$ & -.089 \\
\hline 15. & Tossing a ring over a peg & $.127^{\star}$ & -.101 \\
\hline 3. & $\begin{array}{l}\text { Six standing accuracy ball handlings to a partner from a } 7 \mathrm{~m} \text { distance using one of the techniques } \\
\text { learned }\end{array}$ & $-.031^{\star}$ & -.013 \\
\hline 12. & Rhythmic hand tapping & -.251 & $-.329^{*}$ \\
\hline 13. & Rhythmic movements of upper and lower limbs & -.134 & $-.268^{\star}$ \\
\hline 5. & Sit-ups in 30 seconds & .172 & $-.262^{\star}$ \\
\hline 7. & $\begin{array}{l}\text { Evaluation of the ability to differentiate movement speed (reproduction accuracy of running speed } \\
\text { at } 80 \% \text { intensity of maximum) }\end{array}$ & .085 & $.259^{*}$ \\
\hline 10. & Evaluation of dynamic equilibrium by the BESS method & -.165 & $.235^{\star}$ \\
\hline 14. & Shuttle run $(4 \times 9 \mathrm{~m})$ & .079 & $-.155^{\star}$ \\
\hline
\end{tabular}

Table 5. Classification resultsa. Girls aged 11-13

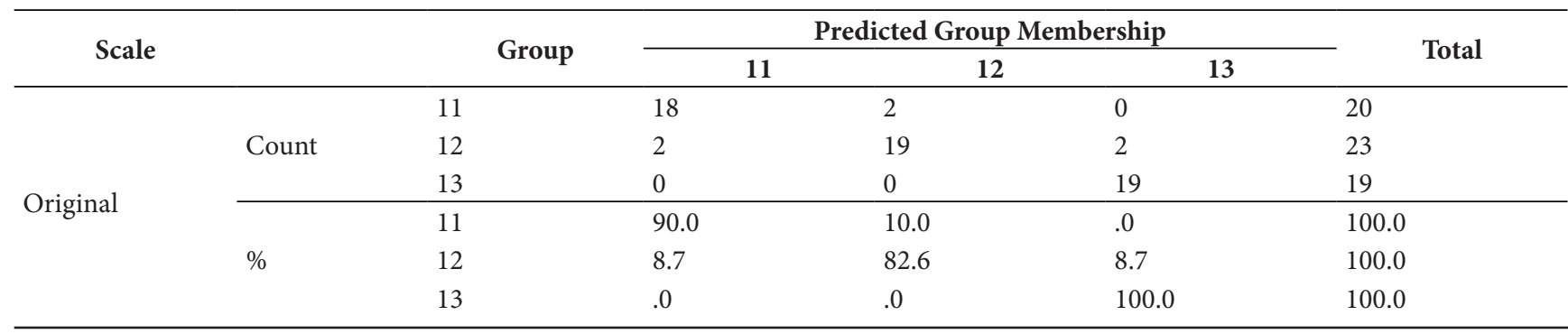

a. $90.3 \%$ of the original grouped cases classified correctly.

Table 4 shows the structure coefficients of the first and second canonical discriminant function, which are the coefficients of correlation between the variables and the function. The first canonical discriminant function is most substantially related to the results of tests 4,16 , 2, 6, 9: thus, a significant difference between the girls aged 11,12 , and 13 is observed in the development level of relative, speed strength, the control of movements by time in short distance running and vestibular analyzer stability. The structure coefficients of the second canonical discriminant function indicate that the function is most substantially related to variables 12 , 13, 5, 7: thus, a significant difference between the girls aged 12 and 13 is observed in movement coordination of arms and legs, strength endurance, and the reproduction accuracy of running speed at $90 \%$ intensity of maximum.

Table 5 shows the classification results of the groups, $90.3 \%$ of the original grouped observations were classified correctly. Therefore, a canonical discriminat func- tion can be used to identify the state of movement coordination development in girls aged 11-13.

\section{Discussion}

The above-mentioned results show that discriminant analysis allows to identify the state of coordination abilities development in the girls aged $11-13$ by the results of testing and supplement the data on the use of discriminant function in classifying schoolchildren by motor activity (Gert-Jan de Bruijn, \& Benjamin Gardner, 2011; Lulzim, 2013). As well as in the works by Geoffrey D. Broadhead and Gabie E. Church (1982), Ivashchenko, Abdulkhalikova, and Cieślicka (2017), the study observed a high discriminant and predictive ability of these functions in evaluating children's and adolescents' motor preparedness.

To practically apply the results of discriminant analysis, the canonical discriminant function coefficients are used (see Table 6). The probability of a case belong- 
ing to the predicted group is calculated by substituting the values of variables that correspond to the case into the discriminant function. By comparing the obtained results with the value of centroids, it is possible to determine the group the result belongs to (Table 7).

It was previously found that the most informative components in the structure of coordination abilities of 5th-7th grade girls are the sense and differentiation of running speed and vestibular stability in exercises that require static and dynamic equilibrium. To carry out pedagogical control of 5th-7th grade girls' coordination preparedness, it is advisable to use the following tests: test 11 "Evaluation of the ability for vestibular (statokinetic) stability. Running with turns", test 9 "Static equilibrium evaluation by E. Ya. Bondarevsky's method", test 6 "Evaluation of the sense of movement speed in sprinting" (Ivashchenko, Prykhodko, \& Cieslicka, 2018).

The discriminant function results allowed to determine that to identify the level of coordination abilities development in boys aged 11, 12 and 13, the following tests can be used: test 9 "Static equilibrium evaluation by E. Ya. Bondarevsky's method" and test 14 "Shuttle run $(4 \times 9 \mathrm{~m})$ ", which characterize vestibular stability and general movement coordination. To identify the state of coordination abilities development in boys aged 12 and 13, the following tests can be used: test 12 "Rhythmic hand tapping", test 13 "Rhythmic movements of upper and lower limbs", and test 15 "Tossing a ring over a peg", which characterize the movement coordination of different parts of the body and accuracy of throwing (Ivashchenko, Khudolii, Iermakov, \& Prykhodko, 2018).
Unlike boys, to identify the level of coordination abilities development in girls aged 11, 12 and 13, it is advisable to use the tests that characterize relative and speed strength, the sense of running speed and vestibular stability. To identify the state of coordination abilities development in girls aged 12 and 13, it is advisable to use the tests that characterize the movement coordination of different parts of the body, strength endurance of abdominal muscles, and the evaluation of the ability to differentiate movement speed. This shows significant differences between boys and girls aged $11-$ 13 in the structure of coordination abilities development and indicates the need to use different programs for developing coordination abilities in boys and girls aged 11-13.

The above-mentioned data supplement the results of Agricola et al. (2015); Palomo-Nieto et al. (2015) on the importance of movement coordination of different parts of the body in evaluating children's and adolescents' coordination abilities, and confirm Ivashchenko's (2016) conclusions as to the evaluation of the current state of motor preparedness using factor analysis, and the evaluation of age-related state dynamics using discriminant analysis that makes it possible to determine informative indicators for a comprehensive control of motor preparedness.

The above-mentioned data supplement the results of the research on the peculiarities of middle school students' motor preparedness (Ivashchenko, O., Khudolii, O., Iermakov, S., Lochbaum, M., Cieślicka, M., Zukow, W., Nosko, M., \& Yermakova, T., 2017; Khudolii, Prykhodko, \& Ivashchenko, 2017).

Table 6. Canonical discriminant function coefficients (unstandardized coefficients). Girls aged 11-13

\begin{tabular}{|c|c|c|c|}
\hline \multirow{2}{*}{ No. } & \multirow{2}{*}{ Test } & \multicolumn{2}{|c|}{ Function } \\
\hline & & 1 & 2 \\
\hline 1. & $30 \mathrm{~m}$ running $(\mathrm{s})$ & -.090 & -.244 \\
\hline 2. & Standing long jump $(\mathrm{cm})$ & .019 & .064 \\
\hline 3. & $\begin{array}{l}\text { Six standing accuracy ball handlings to a partner from a } 7 \mathrm{~m} \text { distance using one of the techniques } \\
\text { learned }\end{array}$ & -.141 & .015 \\
\hline 4. & Pull-ups (number of times) & .209 & -.149 \\
\hline 5. & Sit-ups in 30 seconds & .038 & -.102 \\
\hline 6. & Evaluation of the sense of movement speed in sprinting & -2.290 & 6.474 \\
\hline 7. & $\begin{array}{l}\text { Evaluation of the ability to differentiate movement speed (reproduction accuracy of running speed } \\
\text { at } 80 \% \text { intensity of maximum) }\end{array}$ & -.031 & 4.118 \\
\hline 8. & $\begin{array}{l}\text { Evaluation of the ability to differentiate movement speed (reproduction accuracy of running speed } \\
\text { at } 90 \% \text { intensity of maximum) }\end{array}$ & 2.937 & -2.166 \\
\hline 9. & Static equilibrium evaluation by E. Ya. Bondarevsky's method & .035 & .048 \\
\hline 10. & Evaluation of dynamic equilibrium by the BESS method & -.016 & .034 \\
\hline 11. & Evaluation of the ability for vestibular (statokinetic) stability. Running with turns & .202 & .182 \\
\hline 12. & Rhythmic hand tapping & -.200 & -.387 \\
\hline 13. & Rhythmic movements of upper and lower limbs & -.212 & -.137 \\
\hline 14. & Shuttle run $(4 \times 9 \mathrm{~m})$ & .216 & -.212 \\
\hline 15. & Tossing a ring over a peg & .113 & -.014 \\
\hline 16. & Height $(\mathrm{cm})$ & .079 & -.024 \\
\hline \multirow[t]{2}{*}{17.} & Body weight (kg) & -.020 & .015 \\
\hline & (Constant) & -18.974 & -2.688 \\
\hline
\end{tabular}


Table 7. Functions at group centroids. Girls aged 11-13

\begin{tabular}{lccc}
\hline \multirow{2}{*}{ Group } & \multicolumn{2}{c}{ Function } \\
\cline { 2 - 3 } & $\mathbf{1}$ & $\mathbf{2}$ \\
\hline 11 & -2.131 & .702 \\
12 & -.139 & -1.088 \\
13 & 2.412 & .577 \\
\hline
\end{tabular}

\section{Conclusions}

A discriminant analysis made it possible to determine informative indicators for a comprehensive control of coordination abilities development in girls aged 11-13; to answer the questions as to how the states of coordination abilities development of girls aged 11, 12 and 13 significantly differ; what motor tests most substantially influence the differentiation of classes; what class the object belongs to based on the values of discriminant variables.

To identify the level of coordination abilities development in girls aged 11,12 and 13, the following tests can be used: test 4 "Pull-ups (number of times)", test 2 "Standing long jump $(\mathrm{cm})$ ", test 6 "Evaluation of the sense of movement speed in sprinting", and test 9 "Static equilibrium evaluation by E. Ya. Bondarevsky's method", which characterize relative and speed strength, the sense of running speed and vestibular stability.

To identify the state of coordination abilities development in girls aged 12-13, the following tests can be used: test 12 "Rhythmic hand tapping", test 13 "Rhythmic movements of upper and lower limbs", test 5 "Sit-ups in 30 seconds", test 7 "Evaluation of the ability to differentiate movement speed (reproduction accuracy of running speed at $80 \%$ intensity of maximum)", which characterize the movement coordination of different parts of the body, strength endurance of abdominal muscles, and the evaluation of the ability to differentiate movement speed.

The prospect for further exploration is to study methodological approaches to programming the coordination abilities development in schoolchildren of middle school age.

\section{Acknowledgement}

The study was carried out within the topic 13.04 "Modeling of teaching and motor skills development in children and adolescents" (2013-2014) (state registration number 0113U002102).

\section{Conflict of interest}

The authors declare no conflict of interest.

\section{References}

Bădicu, G. (2018). Physical Activity and Health-Related Quality of Life in Adults from Braşov, Romania. Education Sciences, 8(2). https://doi.org/10.3390/educsci8020052
Bădicu, G., \& Balint, L. (2016). The influence of leisure sports activities on social health in adults. SpringerPlus, 5(1), 1647. https://doi.org/10.1186/s40064-016-3296-9

Balsevich, V.K. (2000). Ontokinesiology of man. M.: Theory and practice of physical culture, 275. (in Russian).

Ilyin, E. P. (2003). Psychomotor organization of man: training for universities. St. Petersburg. : Peter, 384. (in Russian)

Ivashchenko, O.V. (2016). Modelling of physical education students: Monograph. Kharkiv: OVS (in Ukrainian)

Khudolii, O.M., Ivashchenko, O.V., \& Chernenko, S.O. (2015). Simulation of junior shcoolchildren's training to acrobatic exercises and vaults. Pedagogics, Psychology, Medical-Biological Problems Of Physical Training And Sports, 19(7), 64-71. https://doi.org/10.15561/18189172.2015.0709

Ivashchenko, O.V., \& Kapkan, O.O. (2016). Informative pedagogic control indicators of 14-15 years age girls' motor fitness. Pedagogics, Psychology, Medical-Biological Problems Of Physical Training And Sports, 20(6), 18-25. https://doi. org/10.15561/18189172.2016.0603

Emeljanovas, A., Mieziene, B., \& Putriute, V. (2015). The Relationship Between Physical Activity and Content of the Physical Education Classes in 11-12 Years Old Lithuanian Schoolchildren. The Pilot Study. Croatian Journal of Education-Hrvatski Casopis Za Odgoj I Obrazovanje, 17(1), 93-120.

Liakh, V. I. (2000). Driving abilities of schoolchildren: Fundamentals of theory and methods of development. M.: Terra-Sport, 192. (in Russian)

Krutsevych, T. Yu., \& Bezverkhnia, H. V. (2010). Recreation in the physical culture of different population groups: teaching. manual. K. : Olimpiiska literatura, 248. (in Ukrainian)

Iadreev, V., Cherkashin, I., Vujkov, S., \& Drid, P. (2015). Differences in anthropometric, motoric and cognitive abilities between athletically trained and untrained girls. Biomedical Human Kinetics, 7(1), 73-77. https://doi.org/10.1515/bhk-2015-0012

Novak, D., Podnar, H., Emeljanovas, A., \& Marttinen, R. (2015). Comparison of Fitness Levels between Croatian and Lithuanian Students. Montenegrin Journal of Sports Science and Medicine, 4(1), 5-11.

Drid, P., Vujkov, S., Jaksic, D., Trivic, T., Marinkovic, D., \& Bala, G. (2013). Differences in Motor and Cognitive Abilities of Children Depending on Their Body Mass Index and Subcutaneous Adipose Tissue. Collegium Antropologicum, 37(2), 171-177.

Agricola, A., Psotta, R., Abdollahipour, R., \& Nieto, M. P. (2015). The differences of movement between children at risk of developmental coordination disorder and those not at risk. Acta Gymnica, 45(3), 129-138. https://doi.org/10.5507/ag.2015.007

Palomo-Nieto, M., Psotta, R., Agricola, A., Abdollahipour, R., \& Valtr, L. (2015). The effects of various visual conditions on the gait cycle in children with different level of motor coordination - a pilot study. Ricyde- 
Revista Internacional De Ciencias Del Deporte, 11(42), 387-399. https://doi.org/10.5232/ricyde2015.04207

Hadžić, R., Bjelica, D., Vujović, D., \& Popović, S. (2015).

Effects of high-low aerobic program on transformation of motor skills at high school students. Sport Science, 8(1), 79-84.

Khudolii, O.M., \& Ivashchenko, O.V. (2014). Simulation of the learning process and development of motor abilities in children and adolescents: Monograph. Kharkiv : OVS, 320. (in Ukrainian)

Ivashchenko, O., Khudolii, O., Iermakov, S., Lochbaum, M., Cieślicka, M., Zukow, W., Nosko, M., \& Yermakova, T. (2017). Methodological approaches to pedagogical control of the functional and motor fitness of the girls from 7-9 grades. Journal of Physical Education and Sport, 17(1), 254-261.

Khudolii, O.M., Iermakov, S.S., \& Prusik, K. (2015). Classification of motor fitness of 7-9 years old boys. Journal of Physical Education and Sport, 15(2), 245253. https://doi.org/10.7752/jpes.2015.02038

Serhiienko, L. P., Chekmarova, N. H., \& Khadzhynov, V. A. (2012). Psychomotor: Monitoring and Evaluation of Development: [Tutorial]. Kharkiv : OVS, 270. (in Ukrainian)

Khudolii, O.M. (2008). General Fundamentals of Theory and Methodology of Physical Education: A Manual. Kharkiv : OVS. (in Ukrainian)

Lopatiev, A., Ivashchenko, O., Khudolii, O., Pjanylo, Y., Chernenko, S. \& Yermakova, T. (2017). Systemic approach and mathematical modeling in physical education and sports. Journal of Physical Education and Sport (JPES), 17(1), suplement, 146-155

Ivashchenko, O., Prykhodko, V., \& Cieslicka, M. (2018). Movement Coordination: Factor Structure of
Development in 5th-7th Grade Girls. Teoriâ Ta Metodika Fìzičnogo Vihovannâ, 18(1), 38-49. https://doi.org/10.17309/tmfv.2018.1.05

Serhiienko, L. P. (2001). Testing of motor abilities of schoolchildren. K.: Olimpiiska literatura, 439. (in Ukrainian)

Gert-Jan de Bruijn \& Benjamin Gardner (2011) Active Commuting and Habit Strength: An Interactive and Discriminant Analyses Approach. American Journal of Health Promotion, 25(3), e27-e36. https://doi.org/10.4278/ajhp.090521-QUAN-170

Lulzim, I., (2013) Discriminant analysis of morphologic and motor parameters of athlete and non athlete girl pupils of primary school on age 14 to 15 years. RIK(2012), 40(2), 185-190. http://fsprm.mk/wpcontent/uploads/2013/08/Pages-from-Spisanie-RIKbr.-2-2012-9.pdf

Geoffrey D. Broadhead, \& Gabie E. Church. (1982). Discriminant Analysis of Gross and Fine Motor Proficiency Data. Perceptual and Motor Skills, 55(2), 547-552. https://doi.org/10.2466/pms.1982.55.2.547

Khudolii, O.M., Prykhodko, V.V., \& Ivashchenko, O.V. (2017). Features of development of coordination characteristics the girls grades 5-7. Visnyk Chernihivskoho natsionalnoho pedahohichnoho universytetu. Seriia: Pedahohichni nauky. Fizychne vykhovannia ta sport, 1(147), 221-228. (in Ukrainian)

Ivashchenko, O.V., Khudolii, O.M., Iermakov, S.S., \& Prykhodko, V.V. (2018). Coordinating abilities: recognition of a state of development of 11-13 years old boys. Pedagogics, Psychology, Medical-Biological Problems Of Physical Training And Sports, 22(2), 8691. https://doi.org/10.15561/18189172.2018.0204

\title{
КООРДИНАЦІЯ РУХІВ: РОЗПІЗНАННЯ ВІКОВОЇ ДИНАМІКИ РОЗВИТКУ У ДІВЧАТ 11-13 РОКІВ
}

\author{
Іващенко О.В. ${ }^{1}$, Худолій О.М. ${ }^{1}$, Єрмаков С.С. ${ }^{2}$, Приходько В.В. ${ }^{3}$, Цеслицька М. ${ }^{4}$ \\ ${ }^{1}$ Харківський національний педагогічний університет імені Г.С. Сковороди, Україна \\ ${ }^{2}$ Департамент туризму і рекреації, Гданський університет фізичного виховання \\ і спорту, Польща \\ ${ }^{3} \mathrm{HBK}$ «Старт-школа», м. Харків, Україна \\ ${ }^{4}$ Університет Казимира Великого, Бидгощ, Польща \\ Реферат. Стаття: 8 с., 7 табл., 29 джерел.
}

Мета дослідження - визначити можливість розпізнання стану розвитку координаційних здібностей у дівчат 11-13 років на основі методології багатовимірних статистик.

Матеріали і методи. У дослідженні прийняли участь дівчата $11(\mathrm{n}=20), 12(\mathrm{n}=23), 13(\mathrm{n}=19)$ років. Для оцінки рухової підготовленості реєструвалися результати рухових тестів, зріст і маса тіла. Мате- ріали дослідження опрацьовані в програмі статистичного аналізу - IBM SPSS 20. Здійснений дискримінантний аналіз.

Результати дослідження. Для розпізнання рівня розвитку координаційних здібностей у дівчат 11, 12 і 13 років можуть бути використані тести №4 «Згинання й розгинання рук у висі (кількість разів)», №2 «Стрибок у довжину з місця (см)», №6 
«Оцінка відчуття швидкості рухів в спринтерському бігу« і №9 «Оцінка статичної рівноваги за методикою Е.Я. Бондаревського«, які характеризують відносну і швидкісну силу, відчуття швидкості бігу і вестибулярну стійкість.

Для розпізнання стану розвитку координаційних здібностей у дівчат 12 і 13 років можуть бути використані тести №12 «Ритмічне постукування руками», №13 «Ритмічні рухи верхніми і нижніми кінцівкам», №5 «Піднімання тулуба в сід за 30 с», №7 «Оцінка розвитку здібності до диференціювання швидкості рухів (точність відтворення швидкості бігу з інтенсивністю 80\% від максимальної)», які характеризують координацію рухів різними час- тинами тіла, силову витривалість м’язів черевного преса і оцінку розвитку здібності до диференціювання швидкості рухів.

Висновки. Дискримінантний аналіз дозволив визначити інформативні показники для наскрізного контролю розвитку координаційних здібностей у дівчат 11-13 років; дати відповідь на питання наскільки достовірно різниться стан розвитку координаційних здібностей у дівчат 11, 12 і 13 років; які рухові тести найбільш суттєво впливають на розрізнення класів; до якого класу належить об'єкт на основі значень дискримінантних змінних.

Ключові слова. Координаційні здібності, дискримінантний аналіз, педагогічний контроль.

\title{
КООРДИНАЦИЯ ДВИЖЕНИЙ: РАСПОЗНАВАНИЕ ВОЗРАСТНОЙ ДИНАМИКИ РАЗВИТИЯ У ДЕВОЧЕК 11-13 ЛЕТ
}

\author{
Иващенко О.В. ${ }^{1}$, Худолей О.М. ${ }^{,}$, Ермаков С.С. ${ }^{2}$, Приходько В.В. ${ }^{3}$, Цеслицка М. ${ }^{4}$ \\ ${ }^{1}$ Харьковский национальный педагогический университет имени Г.С. Сковороды, \\ Украина \\ ${ }^{2}$ Департамент туризма и рекреации, Гданьский университет физического \\ воспитания и спорта, Польша \\ зУВК «Старт-школа», г. Харьков, Украина \\ ${ }^{4}$ Университет Казимира Великого, Быдгощ, Польша
}

Реферат. Статья: 8 с., 7 табл., 29 источников.

Цель исследования - определить возможность распознавания состояния развития координационных способностей у девочек 11-13 лет на основе методологии многомерных статистик.

Материалы и методы. В исследовании приняли участие девочки $11(\mathrm{n}=20), 12(\mathrm{n}=23), 13$ ( $\mathrm{n}=19)$ лет. Для оценки двигательной подготовленности регистрировались результаты двигательных тестов, рост и масса тела. Материалы исследования обработаны в программе статистического анализа - IBM SPSS 20. Проведен дискриминантный анализ.

Результаты исследования. Для распознавания уровня развития координационных способностей у девочек 11, 12 и 13 лет могут быть использованы тесты №4 «Сгибание и разгибание рук в висе (количество раз)», №2 «Прыжок в длину с места (см)», №6 «Оценка ощущение скорости движений в спринтерском беге»и №9 «Оценка статического равновесия по методике Е.Я. Бондаревского», которые характеризуют относительную и скоростную силу, ощущение скорости бега и вестибулярную устойчивость.

Для распознавания состояния развития координационныхспособностейудевочек 12 и 13 лет могут быть использованы тесты №12 «Ритмичное постукивание руками», № 13 «Ритмичные движения верхними и нижними конечностям», №5 «Подъем туловища в сед за 30 с», №7 «Оценка развития способности к дифференцировке скорости движений (точность воспроизведения скорости бега с интенсивностью $80 \%$ от максимальной)», характеризующих координацию движений различными частями тела, силовую выносливость мышц брюшного пресса и оценку развития способности к дифференцировке скорости движений.

Выводы. Дискриминантный анализ позволил определить информативные показатели для сквозного контроля развития координационных способностей у девочек 11-13 лет; дать ответ на вопрос насколько достоверно отличается состояние развития координационных способностей у девочек 11 , 12 и 13 лет; какие двигательные тесты наиболее существенно влияют на различение классов, к какому классу принадлежит объект на основе значений дискриминантных переменных.

Ключевые слова. Координационные способности, дискриминантный анализ, педагогический контроль. 
Інформація про авторів:

\section{Іващенко Ольга Віталіївна}

https://orcid.org/0000-0002-2708-5636

Харківський національний педагогічний університет імені Г.С. Сковороди, вул. Алчевських, 29, м. Харків, 61003, Україна.

Худолій Олег Миколайович

http://orcid.org/0000-0002-5605-9939

Харківський національний педагогічний університет імені Г.С. Сковороди, вул. Алчевських, 29, м. Харків, 61003, Україна.

\section{Єрмаков Сергій Сидорович}

http://orcid.org/0000-0002-5039-4517

Гданський університет фізичного виховання і спорту вул. Казіміра Горського 1, 80-336 Гданськ, Польща

Приходько Володимир Володимирович

https://orcid.org/0000-0002-9095-0573
НВК «Старт-школа», вул. Садова, 20, м. Харків, 61000, Україна.

Цеслицька Мирослава

https://orcid.org/0000-0002-0407-2592

Інститут фізичної культури університету

Казимира Великого,

вул. Яна Кароля Ходкевича, 30, м. Бидгощ, Польща.

Цитуйте статтю як: Ivashchenko, O.V., Khudolii, O.M., Iermakov, S.S., Prykhodko, V.V., \& Cieslicka, M. (2018).

Movement Coordination: Identification of Age-Related Dynamics of its Development in Girls Aged 11-13. Teoriâ ta Metodika Fizičnogo Vihovannâ [Theory and Methods of the Physical Education], 18(2), 93-101.

https://doi.org/10.17309/tmfv.2018.2.06

Стаття надійшла до редакції: 15.05 .2018 р. Прийнята: 23.06.2018 р. Надрукована: 30.06 .2018 р. 